\title{
THE PREMISES OF A PUBLIC DIALOGUE BETWEEN SCIENCE AND RELIGION
}

\author{
Prof. Ph.D. Florea STEFAN, \\ Doctoral School of Theology „1 Decembrie 1918” University of Alba Iulia, \\ Faculty of Theology and Sciences of Education, Valahia University of Târgovişte, \\ ROMANIA \\ Email:pr_floreastefan@yahoo.com
}

\begin{abstract}
The dialogue between science and religion has always existed. Since it existed, the man was fascinated by everything surrounding him, asking questions, looking for answers, explanations. He wondered why it is what he sees, what he feels, but also what meaning he has to be, which is the purpose for which those are seen. As he understood something, the number of his questions grew, they deepened. There are peoples where the history of knowledge, material and spiritual, has a long tradition. The history of knowledge is part of the heritage of universal history. There are peoples in whom this knowledge has experienced an upward or just sinuous evolution. But with the progress of understanding the world, along with the evolution of science itself, there has also been a breakthrough in human quest for the search for meaning. And it is natural that the scientific explosion of the last decades of the millennium, which has just ended, leads to the intensification of the dialogue between science and religion.
\end{abstract}

Keywords: dialog; religion; science; human; faith; Revelation; knowledge; technique;

\section{INTRODUCTION}

From a Christian perspective, faith is the trust given to a divine person, starting from a set of testimonies, forming the Revelation. It is a grace that is required to be received in all liberty. It introduces itself to a reality that goes beyond our purely empirical or rational investigative possibilities. The content of this Revelation, to which it is trusted, makes place for faith ${ }^{1}$. The role of theology is to make this faith clear and coherent. By its method, it uses all the resources of human sciences. His effort of conceptualization hits boundaries, due to the nature of his essential object: the divine reality. This will never be left behind in concepts, which will have no analogical meaning. Divine reality is mystery. The mystery is not an enigma, that is, something temporarily unknown, waiting for eventual progress in knowledge. In the Christian sense, the mystery is not a misunderstanding, but it will never be constrained by reason. It can only lead us to the threshold of mystery, which remains inexhaustible. "Mystery is the object upon which we will ever end to reflect, in front of him, we are not condemned to silence, but our words are nothing but stammering".

\footnotetext{
${ }^{1}$ Pr. prof. dr. Ion BRIA, Credinţa pe care o mărturisim, IBMBOR, București, 1987, p. 61.

${ }^{2}$ Max PlancK, Despre relaţiile dintre ştiinţă şi religie, în Ştiinţă şi credinţă, XXI Eonul Dogmatic, Bucureşti, 2002, p. 113.
} 
Conditional by a scientific mentality, many of our contemporaries will not be tempted to admit even the notion of mystery. This refusal, one of the characteristics of modernity, meets the refusal of our limits.

But there is also a philosophical or metaphysical belief that allows us to come to terms with a certain idea of God, "understood as the principle and cause of all that exists" (Thomas de Aquino). What are the relationships between this "God of the Philosophers" and "Christian God"? Who does not recall the famous Pascal thought, which opposes the God of Abraham, Isaac and Jacob, who is also Jesus Christ, the God of "philosophers and scholars"? Heidegger ironizes him, in turn, on this God of philosophers, in front of whom you cannot "fall on your knees, sing either instruments or voice or dance." ${ }^{3}$ The God built by metaphysics has too often been described as a little restless, impassioned God, patronizing the world's misfortune in an olympic serenity. Origen, since the third century, has dared to question this impasse: "The Father himself is not impassable ... he suffers a passionate love" ${ }^{4}$, In the fourth century, St. Gregory of Nyssa denounced the danger of a concept of God "who, claiming to attain the divine nature, merely shapes an idol," God can only be known to the extent that he leaves himself known by the Revelation. It is precisely the reason why the Christian God cannot simply be identified with the God of metaphysics. And here we have to make distinction, without separating and uniting without confusion.

The science itself is based on beliefs, which are the subject of a consensus of the scientific community. The truths it reaches are only partial truths, within a field of welldefined reality. It produces models that never identify with the empirical reality in question. When science reflects on its practice, it can only establish its limits.

Especially aimed at action, it has nevertheless revealed the extraordinary internal dynamism, an energy that gives rise to increasingly complex structures and culminates in the brain and the human spirit. Science, at least in part, describes this evolution, but Science is incapable of giving meaning to the essential questions that humanity always puts on: what are we? Where do we come from? Where do we go? Similarly, science proves incapable of establishing an ethics. ${ }^{5}$

Man, in search for landmarks and balance, is called upon to make in himself the synthesis between different beliefs: scientific, philosophical, ethical and religious. This synthesis is a true multidimensional culture. Its scientific component will enable it to escape scientism as well as irrationalism of poor quality (astrology, esoterism, etc.). It is also certain that a good scientific culture will force him to purify some faithful representations. The philosophical component will make it put to its great existential problems. A true religious culture will direct it to the essence of Christian Revelation, which presents a personal God who does not love humanity in general, but every man in particular, reserving for each one an extraordinary destiny. ${ }^{6}$

It is not time to remove the walls of misunderstanding and mistrust that have arisen between our various cultures, each preserving its specificity. But accepting the dialogue with all the others? True dialogue is not an overlap of monologues; it is inseparably linked to extraordinary attention to the views and intuitions of the other.

\footnotetext{
${ }^{3}$ Ibidem, p. 115

${ }^{4}$ Origen apud Ioan G. Coman, Patrologia, Edit. România creştină, Bucureşti, 1999, p. 33.

${ }^{5}$ Nicolae MLadin. Manual de Teologie Morală, Sibiu, 1944, p. 121

${ }^{6}$ Pr. prof. dr. Dumitru PoPESCU, Hristos, Biserică, Societate, E.I.B.M.B.O.R., Bucureşti, 1998, p. 120
} 


\section{RELATIONS BETWEEN SCIENCE AND RELIGION - THE PREMISES OF A RESPONSIBLE DIALOGUE}

When we hear the words science and religion, we immediately think of the tumultuous history of the relationship between them. But the chronicle of meeting religion with science is not just a conflict. There are at least four distinct types of relationships between science and religion:

1) Conflict - the belief that science and religion are fundamentally irreconcilable;

2) Contrast - the view that there is no real conflict between the two, religion and science answering each question totally different;

3) Contact - an approach that seeks dialogue, interaction and possible consonance between science and religion, and especially the ways in which science can shape religious and theological understanding;

4) Confirmation - a slightly more peaceful but extremely important perspective, which clarifies the ways in which religion fully supports and feeds the entire scientific activity.

The delimitation we have made between the four distinct positions of science and religion is of value only if we serve as a starting point for a true dialogue. The process I'm talking about begins with the combination, the undifferentiated mixing of aspects of religion with some scientific ideas, superficially understood. Unless there was such an original confusion of religion with themes that eventually became the exclusive field of science, it is possible that the red flag of the conflict has never been raised. Thus, even if we regard the approach of the conflict as badly guided, we can still appreciate it as an important, perhaps even inevitable, step in the long journey towards a richer understanding.

However, as the process continues to take place, the conflict approach, which firmly opposes the science of religion, seems too extreme, and therefore often claims the more temperate response of the contrast. ${ }^{7}$

The contrast allows us to separate the science of religion without being compelled to regard them as adversaries. It drives them into "so many" games so that combinations and conflicts are no longer possible. We must be particularly grateful for clarification, indeed, for some of us, the way of combining, through conflict, to conversation, must go through the logically precise compartments that are set by contrast.

But many are not content to stay attached to the safety of the contrast. The original dream of a unity of knowledge, our irresistible desire for consistency is not easily lost. Schemed for the first time in naive combination, the passion for synthesis reappears in the third approach (contact), and calling us back from the edge of dualism. After going through conflict and contrast, the path to true conversation must not return to unity without differences. So, contact seeks the relationship, but only on the other side of conflict-induced distinctions and enhanced by contrast.

The fundamental unity of science and religion is anticipated in the most explicit way in the approach we have called a confirmation. This fourth way suggests that science and religion, although different, have a common origin, located in the distant and mysterious source of the human desire for knowledge. Both science and religion ultimately derive from the same "radical" love for truth, which is at the heart of our existence. ${ }^{8}$ Consequently,

\footnotetext{
7 Pr. Dr. Constantin Coman, Ortodoxia sub presiunea istoriei, Edit. Bizantină, Bucureşti, 1995, p. 33

8 John F. HAUGHT., Ştiinţă şi religie - de la conflict la dialog, trad. de Doina Ionescu, Edit. XXI Eonul Dogmatic, Bucureşti, 2002, p. 71.
} 
because of their common origin, consisting of this fundamental concern for the truth, we can not afford to walk in separate ways. ${ }^{9}$

The presence of the Faculty of Theology in the State Universities and the Theological Seminaries in the State Educational Network of Romania is an obvious opportunity and necessity for the dialogue between science and religion in Romania where, for over 40 years, until 1990 the official education The state was based on the conflict between science and religion, while the population of the country remained, despite the state's atheist official ideology, an eminently religious population.

How does the Romanian teacher, student, or pupil reconcile his faith in the world with scientific theories about the world if they are based on conflict or science-religion exclusivity?

By a silent resignation to insurmountable contradiction? Through an attitude of agnosticism or spiritual nihilism? By replacing the passion for truth with an apathy of the thirst for knowledge? Souls and living consciences are not content with these solutions, but they make the search the proof of their own growth. That is why both the passion for scientific research and the passion for deepening religious spiritual life are necessary for a fruitful and mutually enriching dialogue, from which the joy of complementarity and the sense of co-responsibility can give birth.

The ecclesial Orthodox tradition, based on the patristic theological synthesis, is a solid support for a contemporary dialogue between science and religion, because the holy Fathers of the Church have used expressions and knowledge in the sciences of their time to interpret the revealed truths for the benefit of life and salvation, as the truths of the communion of life and love of God the Creator with His creation. An eloquent example in this regard is St. Basil the Great, through his Commentary on Hexaimeron. "The Truth is God Himself. In this sense, revelation-based theology analyzes God and His works outside of His Being, but also all His works and beings created by Him as they stand in relation to God the Creator, the Provident and the Savior. So in this aspect as in philosophy, any natural or human phenomenon in this world can be analyzed from the theological perspective. Anything or phenomenon can become the subject of Christian theology: the world, nature, the environment, science, man himself, creation etc. "10

Of course, today's theologians need not only to repeat the Holy Fathers, but in spiritual communion with them, to do for our time what they have done for their time: to have an attitude of respect and to receive discernment of the results of knowledge humanbased research. $^{11}$

On the other hand, the Holy Fathers did not confuse science with faith, nor did they substitute the ancient philosophy or human sciences of their time for divine biblical Revelation, teaching that the excessive rationalization of the mystery of existence leads to the reductionism that hinders true knowledge. Their logical and systematic thinking is always combined with an antinomic and apophatic thought, open to mystery, as an inexhaustible fullness of knowledge.

\footnotetext{
$9 \dagger$ Anastasios Yannoulatos, Arhiepiscop al Tiranei şi Primat al întregii Albanii, Ortodoxia şi problemele lumii contemporane, Edit. Bizantină, Bucureşti, 2003, p. 211

${ }^{10}$ Prof. Marin Bugiulescu, Philosophy and Theology. Science and Knowledge, Truth and Life, International Journal of Theology, Philosophy and Science Number 1, Year I, May-November 2017, p. 6

${ }^{11}$ Pr. Prof. Dumitru POPESCU, Teologie şi cultură, E.I.B.M.B.O.R., Bucureşti, 1993, p. 88.
} 
The quantum mechanics of non-determinism and the theory of space and time relativity make the scientific description of the universe today a probabilistic description in which it is possible to act God without prejudice to scientific legality ${ }^{12}$.

\section{THE NEED FOR DIALOGUE BETWEEN SCIENCE AND RELIGION}

Science, based on research and analysis, reveals the structure of the universe, while faith, based on the Divine Revelation, reveals the ultimate meaning and purpose of the universe. When science discovers the structure of the universe, it is possible to establish a relationship between the human intelligence and the intelligibility of the structure of the universe and the laws governing it, which can lead to the understanding that the structure of the universe is the result of an Intelligence that made the universe, while faith is the spiritual capacity to see the Unseen One (Hebrews 11:27) beyond the physical world's visibility. ${ }^{13}$

The structure of the universe that science discovers can be interpreted by the way of repetition and the combination of its basic elements as multiple languages. Faith is the view of this language imprinted in the universe by the Creator: "The heavens say the glory of God, and the making of His hands proclaims the strength (firmament)" (Psalm 18: 1).

The structure of the universe as a non-verbal and complex information language, which science can observe, can strengthen faith as a view of the unseen and understanding of the existence of transcendent creative Intelligence: "God's invisible things are seen from the world, understanding of the beings, that is, his eternal power and godliness "(Romans 1:20).

Dialogue between Science and Faith as an effort to discern in the universe the value of the communion between uncreated intelligence and intelligence created.

The active human rationality in scientific research, which discovers the rationality of the universe in its structure and the laws governing it, maintaining its dynamic identity in expansion, can be interpreted in dialogue with faith as the reflex and gift of divine Reason and as a way to, in order for a communion of multiple and inexhaustible love in its novelty, which does not abolish reason, but trans-sciences that, from the power of search and encompassment, it becomes a capacity of sharing from the reciprocal interior between Creator and creation.

Science discovers the age and aging of the universe, but it does not rule out the probability of its new future, while faith anticipates the gift promised by the Creator: "Heaven and the new earth" (Revelation 21: 1), which may confirm that the relativity of space and time is preparing the passage and transfiguration of the current mode of existence into a new one, in which full science will be identified with holiness! ${ }^{14}$ In this sense, in the near future, only a mystical and sacramental theology can carry a profound and fertile dialogue with a science that becomes more and more open to the relationship between perhaps and mystery. ${ }^{15}$

Thus, the mystery, approached suddenly by science and faith, could be perceived, antinomically and fascinatingly, as the inevitable basis of true knowledge, precisely because this knowledge is not confused with the certainty of self-sufficiency, since the seeker / researcher himself belongs of mystery, it is its interior, not its exterior.

\footnotetext{
12 I.P.S. Daniel СıовотEA, Necesitatea dialogului între ştiinţă si religie astăzi, în Ştiinţă şi religie antagonism sau complementaritate, XXI Eonul Dogmatic, Bucureşti, 2002, p. 24.

$13+$ Anastasios YanNOUlatos, op.cit., p. 213.

${ }^{14}$ Ilarion FelEA, Religia culturii, Edit. Episcopiei ortodoxe române a Aradului, Bucureşti, 1994, p. 175.

$15+$ Antonie PlăMĂDEALĂ, Biserica în mers, vol 2, Edit. Mitropoliei, Sibiu, 1999, p. 33.
} 
The dialogue between Science and Faith will strengthen co-responsibility and love for creation. If the dialogue will facilitate a deeper understanding of the world as the cognitive language of communion, to be deciphered by science and holiness, and as a giftsacrament or meeting place between uncreated love and loving beings created, it will be better understood what is deforming the surrounding nature and man, and what transfigures and gives full life to nature and man. In other words, the dialogue will facilitate a deeper understanding of the relationship between the current ecological crisis, the environment and the spiritual crisis of human interiority, because the spiritual inner person's inspiration inspires its external behavior. An authentic dialogue between Science and Religion can be a chance to love God the Creator, the man created in the image of the Creator and the whole nature - as a multiplier of the Creator for the intelligent and loving beings capable of Multiple and New Dialogue with Him. ${ }^{16}$

\section{RELIGION - AND SCIENCE: DISTINCT, BUT COMPLEMENT}

Religion is the direct and cultivated relationship of man with God-the Creator of the world, and culture is the way man (people and peoples) understands and uses the world created by God; culture is the whole of man-made relationships in his contact with the surrounding existence: from the way man cultivates the earth and studies the stars, to the way he cultivates friendship and poetry. Through science, man expresses both his way of life in this world and his belief and understanding of life and his role in the world. In its normal state, as the Creator wants, the whole existence or activity of man is somewhat cultic, religious, as it takes place in the presence and creation of God. Man was created in the image of God (cf. Genesis 1: 26) to represent and glorify the God-Creator on earth by what he does in this world. But sin as the weakening or breaking of man's living bond with God-Creator makes man no longer perceive the spiritual presence of the Creator in the world. As such, the world of people is no longer for the man and the world of God, and science loses in its consciousness its dimension to cultivate the recognition and exalting of the creative gifts the Creator has planted in men that through them can be cultivated communion life and love with God and the whole.

A theological analysis of the history of humanity shows that when weak people's faith in God-Creator, their culture is filled with idols or false gods. ${ }^{17}$ Religion as the relationship of man with God-Creator, distinct from the world but not absent from it, helps man to maintain both his consciousness of free and superior being in relation to the other creatures, and consciousness of being responsible to the Creator, of God.

Because through Religion man cultivates the relationship with God-Creator, religious cult is the essential form of soul culture. That is why "the soul of culture is the culture of the soul". ${ }^{18}$

In the last analysis, cult, as an expression of faith in God, is a state and a work of acknowledgment and gratitude of man to God-his Creator and to the whole world, and culture is, in its most authentic form, the celebration of existence active of man in the world created by God and in dialogue with it. And because God cannot be understood without the world and the world without God, faith needs culture and culture needs faith.

\footnotetext{
${ }^{16}$ Pr. Lect. Univ. Dr. Mihai HIMCINSCHI, Misiune şi Dialog: ontologia misionară a Bisericii din perspectiva dialogului religios, Edit. Reîntregirea, Alba Iulia, 2004, p. 89

${ }^{17}$ Daniel CioboteA, Dăruire şi dăinuire, Trinitas, Iaşi, 2005, p. 36.

18 Ibidem, p. 39
} 
So, Religion and Culture are not two parallel entities, but they, though distinct, intertwine and contain each other. Culture gives fertile soil to faith, and faith creates the perenniality of culture as a liturgy of the history of a people, committed in becoming and persevering in the glory of God - the Lord of History and the Lover of Men.

\section{DIFFERENT ATITUDES TO SCIENCE}

Modern science has become a social reality of the first magnitude, both through civilization, whose production has an important contribution, and by the mentalities it shapes. Scientific research has a twofold aspect: science, pure and pure, which teaches the laws and constructs the theories, and applied science, which deals with technological achievements. The public tends to confuse the two aspects. It is true that science and technology live in symbiosis and support each other. We plan to examine the attitudes of our contemporaries to this great phenomenon of society, which became science. These attitudes go from infinite enthusiasm to explicit hostility. ${ }^{19}$

Science has become the dominant knowledge. Contrary to a widespread view, scientism, which characterized the 19th century, has not disappeared. The scientific ideology is maintained, but in a somewhat subtle form. Pierre Thuillier summed up this ideology in three postulates or "articles of faith"20:

- science is the only authentic knowledge, so the best of knowledge;

- science is capable of answering all theoretical problems, is capable of solving all practical problems, provided that they are formulated in rational terms;

- it is legitimate and desirable to be entrusted to scientific experts to care for all human problems, whether politics, economy, morality etc. ${ }^{21}$

These postulates are rarely explicitly stated, everything happens as if they were by themselves. It is preferable only to mention the slogans, such as "science in the service of man, progress and freedom", which flourish in official speeches. Scientism circulates an image of science that we might qualify as mythical. It would appear as a kingdom of certainties, pure rationality; her successes plead for her infallibility; it has freed us from our old religious and moral prejudices and strikes in a divine innocence. It is surprising that scientist ideology finds its defense, not just those who ignore everything from the proper functioning of scientific research, but even among eminent scientists. Jacques Monod, the Nobel Prize for Biology, has become the promoter of a knowledge ethic in search of scientific milestones capable of allowing us to decide what is right and what is bad.

\section{CONCLUSION}

Science does not only inspire enthusiasm or fear, but also a strange fascination for many. This gave rise to the theory of concordance, which states that there should be a perfect agreement between the Bible's and the science's statements. In a broader sense, concordism is an attempt to want to confirm religious truths based on scientific truths. This kind of concordism is very old; the blessed Augustine did not hesitate to support his thoughts on the soul through "demonstrations" taken from geometry. Other authors assimilated the six "days" of biblical creation with subsequent geological periods. The big bang theory has been interpreted by some as a decisive confirmation of the idea of creation. Historian Pierre

\footnotetext{
${ }^{19}$ Ibidem, p. 51

${ }^{20}$ Pierre THUILLIER, in: Jacques Paul, Biserica şi cultura în Occident, 2 volume, Edit. Meridiane, Bucureşti, 1996, p. 110

${ }^{21}$ Olivier Clement, Bazele spirituale ale viitorului, Edit. Galaxia Gutenberg, Târgu Lăpuş, 2004, p. 82
} 
Chaunu has stated in several papers the concordance between Big Bang and Fiat Lux in the Bible. Astrophysicist Trinh Xuan Thuan notes that "the idea of the birth ex nihilo, which still belonged to religion yesterday, seems to have found today a scientific support in cosmology". ${ }^{22}$ It can only be a false resemblance, because the quantum vision has nothing to do with the biblical «nihil». In a recent work, Jean Guitton states: "There is no evidence now - God is not in the order of demonstration - but a scientific support point for the conception of religion." In the preface of his book, we read: "Is not God now, sensible, observable, and almost visible, on the ultimate background of the reality described by nature?" This defective mix of genres is the very definition that P. Ricoeur word "compromise". ${ }^{23}$

We can associate the concordism with the tendency to want to artificially unify different fields, such as the theologies and natural sciences. The theologian who went the furthest way in this respect is Jürgen Moltmann in his work "God in Creation". In what terms does he formulate the project: "We deliberately give up delimitation, from a fearful concern for our own identity, between the theological doctrine of creation and the natural sciences and their scientific theories". ${ }^{24}$

John Paul II seems to have realized the danger of "criticizing, uncritically and too hurriedly, for apologetic purposes, recent theories, like that of the big bang in cosmology." The theme to which he is well-known is, to say true, the rather ambiguous of unity of knowledge. "Reality is one, and truth is one, and we affirm that there is an intrinsic call to the unity of knowledge that comes from experimental science or theology." "Unity is one of the predicates of truth." "Science is the quest for unity." ${ }^{25}$ But the fecundity of the scientific method does not come precisely from the fact that it operates a decoupling of reality in delimited areas, within which it can reach a certain truth? When it is stated that "faith and science are intrinsically ordered in the same object, the ultimate truth which is God", would it be worthwhile to specify what science is: experimental science or theological science?

Addressing a responsible and authentic dialogue between religion and science requires first of all a common ground. It is said that science teaches how the heavens are going, and religion how to go to heaven, how to get to God. But the two can only be complementary. The fundamental unity of science and religion is anticipated in the most explicit way in the approach we have called a confirmation. This path suggests that science and religion, though different, have a common origin, located in the distant and mysterious source of the human desire for knowledge. Both science and religion ultimately derive from the same "radical" love for truth, which is at the heart of our existence. Consequently, because of their common origin, consisting of this fundamental concern for the truth, we cannot afford to walk in separate ways.

The ecclesial Orthodox tradition, based on the patristic theological synthesis, is a solid support for a contemporary dialogue between science and religion, because the holy Fathers of the Church have used expressions and knowledge in the sciences of their time to interpret the revealed truths for the benefit of life and salvation, as the truths of the communion of life and love of God the Creator with His creation. An eloquent example in this regard is St. Basil the Great, through his Commentary on Hexaimeron. Of course, today's theologians need not only to repeat the Holy Fathers, but in spiritual communion with them, to do for our time

\footnotetext{
${ }^{22}$ Ibidem, p. 62

${ }^{23}$ Jacques PAUL, Biserica şi cultura în Occident vol 2 , Edit. Meridiane, Bucureşti, 1996, p. 317

${ }^{24}$ Ibidem, p. 322

${ }^{25}$ Scripcaru Gh., Ciuca A., Astarastoae V., Bioetica, stiintele vietii si drepturile omului, Edit. Polirom, Iaşi, 1998, p. 25
} 
what they have done for their time: to have an attitude of respect and to receive discernment of the results of knowledge human-based research.

An authentic dialogue between the Church's people and scientific scholars can only take place from the knowledge and acceptance of their own limits. Without this fundamental principle, Religion becomes exclusive and absolutist and Science will claim to have absolute truth. But the truth is not possessed, once it shares a committed and responsible dialogue that will eventually lead to communion.

\section{BIBLIOGRAPHY:}

[1] *** Vocabular de Teologie Biblică, publicat sub conducerea lui Xavier Leon - Dufour, Ed. Arhiepiscopiei Romano - Catolice, Bucureşti, 2001.

[2] ANASTASIOS Yannoulatos, Arhiepiscop al Tiranei şi Primat al întregii Albanii, Ortodoxia şi problemele lumii contemporane, Ed. Bizantină, Bucureşti, 2003.

[3] ANTONIE Plămădeală, Biserica în mers - 2 vol, Ed. Mitropoliei, Sibiu, 1999.

[4] BRIA, Pr. Prof. Dr., Ion, Credinţa pe care o mărturisim, Editura IBM al BOR, Bucureşti, 1987.

[5] BRIA, Pr. Prof. Dr., Ion, Dicţionar de Teologie Ortodoxă, E.I.B.M. al B.O.R., Bucureşti, 1994.

[6] BUGIUlESCU, Prof. Marin, Philosophy and Theology. Science and Knowledge, Truth and Life, International Journal of Theology, Philosophy and Science Number 1, Year I, May-November 2017

[7] CLEMENT, Olivier, Bazele spirituale ale viitorului, Ed. Galaxia Gutenberg, Târgu Lăpuş, 2004.

[8] CIOBOTEA, Daniel Necesitatea dialogului între ştiinţă si religie astăzi, în Ştiinţă şi religie antagonism sau complementaritate. Editura XXI Eonul Dogmatic, Bucureşti, 2002

[9] CIOBOTEA, Daniel, Dăruire şi dăinuire. Editura Trinitas, Iaşi, 2005

[10]COMAN, Pr. Dr., Constantin, Ortrodoxia sub presiunea istoriei, Ed. Bizantină, Bucureşti, 1995.

[11]DAMASKINOS, Papandreou, Mitropolitul ortodox al Elveţiei, Biserică, Societate, Lume, Ed. Trinitas, Iaşi, 1999.

[12]HIMCINSCHI, Pr. Lect. Univ. Dr, Mihai, Misiune şi Dialog: ontologia misionară a Bisericii din perspectiva dialogului religios, Ed. Reîntregirea, Alba Iulia, 2004.

[13]IOAN PAUL al II-lea, Papă, Planul lui Dumnezeu, Ed. Enciclopedică, Bucureşti, 1999.

[14]FELEA, Ilarion, Religia culturii, Editura Episcopiei ortodoxe române a Aradului, Bucureşti, 1994

[15]HAUGHT John F., Ştiinţă şi religie - de la conflict la dialog, trad. de Doina Ionescu, Editura XXI Eonul Dogmatic, Bucureşti, 2002

[16]MLADIN Nicolae, Manual de Teologie Morală, Sibiu, 1944

[17]PLANCK, Max, Despre relaţiile dintre ştiinţă şi religie, în Ştiinţă şi credinţă , Editura XXI Eonul Dogmatic, Bucureşti, 2002

[18]PAUL, Jacques, Biserica şi cultura în Occident - 2 volume, Ed. Meridiane, Bucureşti, 1996.

[19]POPESCU, Pr. prof. dr. Dumitru, Hristos, Biserică, Societate, E.I.B.M. al B.O.R., Bucureşti, 1998.

[20]SCRIPCARU Gh., CIUCA A., ASTARASTOAE V., Bioetica, stiintele vietii si drepturile omului, Ed. Polirom, Iaşi, 1998

[21]STAN George, Teologie si Bioetica, Ed. Biserica Ortodoxa, Alexandria, 2001

[22]STANCIU, Mihail, Sensul creatiei, Asezamantul studentesc Sf Ap Andrei, Slobozia, 2000

[23]STOICA, pr. dr, Ion, Adevărul, lumea şi omul - repere pentru o abordare metarealistă al întîlnirii religiei cu ştiinţa, Ed. Asa, Bucureşti, 2006 